\title{
NOTE
}

\section{Determination of zooplankton characteristics in the presence of surface feeding basking sharks Cetorhinus maximus}

\author{
D. W. Sims*, D. A. Merrett \\ Department of Biological Sciences, and Plymouth Environmental Research Centre, University of Plymouth, Drake Circus, \\ Plymouth PL4 8AA, United Kingdom
}

\begin{abstract}
Zooplankton samples were taken in the presence $(n=68)$ and absence $(n=65)$ of surface feeding, zooplanktivorous basking sharks Cetorhinus maximus off Plymouth, southwest England, from May to mid-August, 1995-96. A preliminary study in 1995 showed zooplankton density $\left(\mathrm{g} \mathrm{m}^{-3}\right)$ to be $46 \%$ higher in samples taken near feeding sharks. Calanoid copepods predominated in all samples, but were $84 \%$ more numerous and $23 \%$ longer in shark samples. A second study in 1996 comprising 110 samples showed a $75 \%$ increase in zooplankton density near feeding sharks. The total number of copepods present per $\mathrm{m}^{3}$ was not significantly different compared to non-shark samples, but counts of copepod species numbers showed clear differences between shark and non-shark samples which accounted for the increase in biomass per $\mathrm{m}^{3}$ observed near feeding sharks. Compared to where sharks were absent, samples taken near feeding sharks contained 2.5 times as many Calanus helgolandicus individuals per $\mathrm{m}^{3}$, which were also $50 \%$ longer, together with fewer of the smaller copepods, Temora longicornis and Acartia clausi (58 and $33 \%$ reductions in no. $\mathrm{m}^{-3}$, respectively). There were approximately equal numbers of

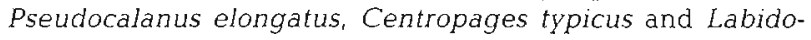
cera wollastoni in shark and non-shark samples. These results show basking sharks off Plymouth were found surface feeding in patches containing abundant large $C$. helgolandicus with fewer numbers of smaller species, which together acted to significantly increase the biomass per $\mathrm{m}^{3}$ where sharks were feeding, compared to areas where they were absent. On the basis of this study, the hypothesis that basking sharks forage actively to locate more productive zooplankton patches can be supported.
\end{abstract}

KEY WORDS: Basking shark - Zooplankton $\cdot$ Calanus $\cdot$ Foraging Orientation behaviour

The majority of over 370 species of shark are macropredators and scavengers, while only 3 species obtain food by filtering seawater (Compagno 1984). These however, are among the largest living sharks, and among marine vertebrates only whales are larger. The

•E-mail: dwsims@plymouth.ac.uk basking shark Cetorhinus maximus is a coastal-pelagic shark known to inhabit the boreal to warm temperate waters of the continental and insular shelves circumglobally (Compagno 1984). In the northwest and east Atlantic they occur in coastal regions from April to October, usually with a peak in sightings from May until August (Kenney et al. 1985, Berrow \& Heardman 1994). They are seen frequently around the north, west and southwest coasts of Britain at the water's surface during summer months (Matthews \& Parker 1950, Berrow \& Heardman 1994). They filter-feed on zooplankton by swimming open-mouthed, creating a passive flow of water across the gills that leaves via the greatly enlarged gill slits (Diamond 1985). Filamentous rakers attached to gill arches trap or deflect food particles onto mucus covering the arches (Matthews \& Parker 1950). Generally the mouth remains open for 30 to 60 s before it closes momentarily and the plankton and mucus are swallowed (Hallacher 1977): Detailed studies of stomach contents are lacking, but C. maximus has been stated to be an indiscriminate zooplankton feeder where the principal filtered prey item is simply that dominant at any particular time and place (Matthews \& Parker 1950). From this it has been proposed that $C$. maximus is unlikely to orient to particular types of plankton-rich water (Matthews \& Parker 1950).

Zooplankton in temperate regions is both temporally and spatially heterogeneous (Tait 1980) and in winter when food is scarce, basking sharks apparently shed their gill rakers and fast, presumably because feeding becomes energetically prohibitive (Parker \& Boeseman 1954). In these terms, the basking shark is unique among aquatic vertebrates in being an obligate ram filter-feeder that sheds its filtering apparatus during winter months. To survive, basking sharks must solve the problem of having to locate and capture enough 


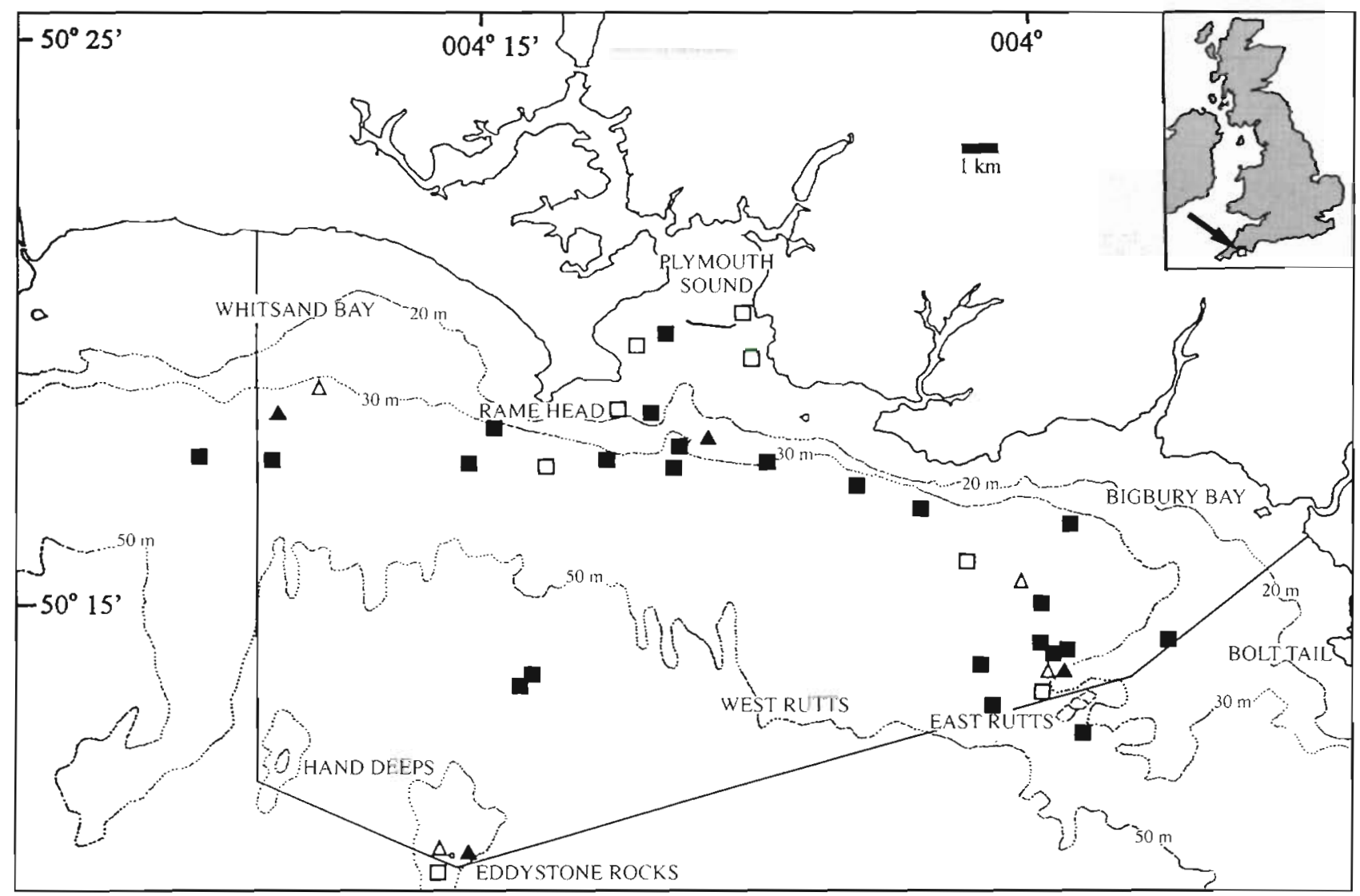

Fig. 1. Plymouth area of southwest England (arrowed in inset map) shown with the study area perimeter, sampling stations used in $1995(\Delta)$ and $1996(\mathbf{A})$ and the locations where solitary or grouped Cetorhinus maximus were surface feeding in $1995(\square)$ and 1996 (ם). Scale bar $=1 \mathrm{~km}$

patchily distributed plankton within a restricted feeding season in coastal areas. The question is, do basking sharks orient specifically to waters containing high numbers of zooplankton as a behavioural strategy to maximise prey encounter rates?

Very little is known about the life-history of basking sharks (e.g. reproduction, fecundity, growth rates, migrations) and apart from anecdotal descriptions of feeding behaviour (Matthews \& Parker 1950, Hallacher 1977) there have been no investigations of their foraging behaviour. In this manuscript we describe the zooplankton characteristics where basking sharks were surface feeding compared to when no sharks were present. The aim of the study was to ascertain whether basking sharks occur in sea areas of specific zooplankton characteristics, a behaviour that might be suggestive of active orientation to productive patches.

Materials and methods. Zooplankton samples were taken in the presence and absence of surface feeding basking sharks. Samples taken when sharks were absent were from 4 stations in both 1995 and 1996 (Fig. 1). In 1995, 15 samples were taken in total $(3,5,2$ and 5 total samples per station) between 11:00 and 13:00 $\mathrm{h}$, and in 1996, 50 station samples were taken $(19,13,2$ and 16 in total per station) between 10:00 and 14:00 h. The set stations were situated in areas where basking sharks were seen in abundance in both of these years (Fig. 1). The non-shark samples were of 2 types: (1) samples taken at the stations when sharks were absent, but before or after sharks were sighted feeding in the vicinity that day (between 2 and $5 \mathrm{~km}$ from sample stations), (2) samples taken at stations when sharks were absent, and when no sharks were seen that day. A zooplankton sample consisted of 3 vertical hauls from $10 \mathrm{~m}$ depth of a weighted simple plankton net net diameter $=30 \mathrm{~cm}$, mesh diameter $=$ $0.25 \mathrm{~mm}$ ). Each haul was made in close succession with the zooplankton removed by seawater washing after each haul. The plankton from the 3 hauls were pooled into a single sample and fixed immediately in $4 \%$ formaldehyde.

Zooplankton samples were also taken in the presence of surface feeding basking sharks, which were sighted by visual surveys undertaken on a research 
vessel within a $350 \mathrm{~km}^{2}$ study area in the Plymouth, UK, region of the English Channel (Fig. 1). Daily daytime searches within this area were carried out from May to mid-August in 1995 and 1996. When sharks were seen feeding at the surface they were approached slowly and their position determined using a Global Positioning System. The vessel remained within $50 \mathrm{~m}$ of the sharks at all times, mostly with the engine disengaged, the vessel drifting in the same direction as the resultant movements of the feeding sharks. When sharks passed close to the vessel $(<3 \mathrm{~m})$ and were feeding, a zooplankton sample was taken in front of, or to the side of, an oncoming shark. Samples were taken every $30 \mathrm{~min}$ during the time sharks remained at the surface feeding, with solitary and grouped (between 2 and 12) sharks being tracked during 1995-96.

Total zooplankton catch in each sample was filtered and weighed wet, then carefully resuspended in $70 \%$ ethanol. All sample bottles were coded and their provenance withheld from sorters to avoid bias. In 1995, zooplankton was counted by pouring each sample into a Bogorov tray. Animals from the main representative taxa were counted, which included all nonnaupliar calanoid copepods (stages CI to CVI; Green et al. 1993), mysid and decapod larvae, chaetognaths, larvaceans, polychaetes, cladocerans, and fish larvae, post-larvae and eggs. To find out whether copepods where sharks were feeding were larger than in nonfeeding areas, 24 calanoid copepods in each sample were staged at random and the length of the prosome determined using a calibrated eyepiece graticule.

Each zooplankton sample taken in 1996 was reduced using a standard plankton splitter to obtain subsamples. Between 1 and 4 splits were made to the samples. Validations of our technique, by comparison of the number of copepods determined from a split subsample to the entire counted sample, showed there to be a mean error of $6.4 \%( \pm 1.64 \mathrm{SE}, \mathrm{n}=5)$. The main species of calanoid copepods were identified (Todd et al. 1996) and counted in each subsample. The prosome lengths of 24 Calanus helgolandicus staged at random per subsample were measured because although this species predominated in all samples, larger individuals may have been characteristic of shark feeding areas.

Zooplankton samples from 1996 were analysed both qualitatively and quantitatively for differences between zooplankton characteristics in basking shark feeding areas (shark samples) compared to where sharks were absent (non-shark samples). Qualitative analyses were undertaken on 4 parameters of zooplankton characteristics, namely, zooplankton density $\left(\mathrm{g} \mathrm{m}^{-3}\right)$, number of calanoid copepods (no. $\left.\mathrm{m}^{-3}\right)$, number of $C$. helgolandicus, and mean length of $C$. helgolandicus ( $\mathrm{mm}$ ) to obtain a measure of median dispersion between shark and non-shark samples. Shark and non-shark sample values corresponding to each parameter separately were ranked highest to lowest and the percentage of ranks above the median rank ( $\mathrm{R}=$ 55) was calculated for shark and non-shark conditions, for each of the 4 parameters.

The same 4 parameter-ranked data streams were then used to obtain a quantitative measure of any significant dispersion between the shark and non-shark samples. Differences in dispersion of the aforementioned parameter ranks, in addition to the ranks of numbers per $\mathrm{m}^{3}$ of each of the remaining copepod species (Temora longicornis, Acartia clausi, Pseudocalanus elongatus, Centropages typicus and Labidocera wollastoni) between shark and non-shark samples, were tested using Mann-Whitney 2-tailed $U$-tests with tied ranks, with the normal approximation and $Z$-transformation with $p<0.05$ (Zar 1984). In total, 9 quantitative tests were performed, 1 for each zooplankton parameter combining shark and non-shark samples.

Results. From the preliminary study in 1995 it was clear that copepods predominated in all samples such that when more numerous, the overall zooplankton density was increased (Table 1). Where sharks were

Table 1. Characteristics of zooplankton measured when sharks were absent ( $\mathrm{n}=15)$, and within $3 \mathrm{~m}$ of feeding sharks $(\mathrm{n}=8)$ between May and mid-August 1995

\begin{tabular}{|c|c|c|c|c|c|c|c|c|}
\hline & $\begin{array}{l}\text { Density } \\
\left(\mathrm{g} \mathrm{m}^{-3}\right)\end{array}$ & $\begin{array}{l}\text { Copepods } \\
\left(\text { no. } \mathrm{m}^{-3} \text { ) }\right.\end{array}$ & $\begin{array}{l}\text { Copepod } \\
\text { mean } \\
\text { length } \\
(\mathrm{mm})\end{array}$ & $\begin{array}{l}\text { Mysid and } \\
\text { decapod } \\
\text { larvae } \\
\left(\text { no. } \mathrm{m}^{-3}\right)\end{array}$ & $\begin{array}{c}\text { Chaetognaths } \\
\text { and } \\
\text { larvaceans } \\
\text { (no. } \mathrm{m}^{-3} \text { ) }\end{array}$ & $\begin{array}{l}\text { Polychaeta } \\
\text { (no. } \mathrm{m}^{-3} \text { ) }\end{array}$ & $\begin{array}{l}\text { Cladocerans } \\
\text { (no. } \mathrm{m}^{-3} \text { ) }\end{array}$ & $\begin{array}{c}\text { Fish larvae, } \\
\text { post-larvae } \\
\text { and fish eggs } \\
\left(\text { no. } \mathrm{m}^{-3}\right)\end{array}$ \\
\hline \multicolumn{9}{|c|}{ Sharks absent } \\
\hline Mean & 1.26 & 374.91 & 1.38 & 29.78 & 130.41 & 0.72 & 451.07 & 8.15 \\
\hline SE & 0.07 & 115.05 & 0.07 & 7.12 & 7.12 & 0.35 & 106.37 & 1.56 \\
\hline Median & 1.20 & 246.70 & 1.43 & 22.17 & 108.02 & 0 & 337.26 & 7.55 \\
\hline \multicolumn{9}{|c|}{ Sharks present } \\
\hline Mean & 1.84 & 691.21 & 1.70 & 29.42 & 40.39 & 2.89 & 298.35 & 8.20 \\
\hline $\mathrm{SE}$ & 0.33 & 218.60 & 0.14 & 8.52 & 12.26 & 1.78 & 116.77 & 1.16 \\
\hline Median & 1.31 & 429.72 & 1.77 & 20.99 & 30.90 & 1.42 & 263.67 & 8.50 \\
\hline
\end{tabular}


Table 2. Zooplankton density and copepod species abundances measured when sharks were absent ( $\mathrm{n}=50$ ), and from shark feeding paths $(n=60)$ between May and mid-August 1996

\begin{tabular}{|c|c|c|c|c|c|c|c|c|c|}
\hline & $\begin{array}{l}\text { Density } \\
\left(\mathrm{g} \mathrm{m}^{-3}\right)\end{array}$ & $\begin{array}{l}\text { Copepods } \\
\text { (no. } \mathrm{m}^{-3} \text { ) }\end{array}$ & $\begin{array}{l}\text { Calanus } \\
\text { helgo- } \\
\text { landicus } \\
\text { (no. } \mathrm{m}^{-3} \text { ) }\end{array}$ & $\begin{array}{c}\text { C. helgo- } \\
\text { landicus } \\
\text { mean length } \\
(\mathrm{mm})\end{array}$ & $\begin{array}{c}\text { Temora } \\
\text { longicornis } \\
\text { (no. } \mathrm{m}^{-3} \text { ) }\end{array}$ & $\begin{array}{l}\text { Pseudo- } \\
\text { calanus } \\
\text { elongatus } \\
\text { (no. } \mathrm{m}^{-3} \text { ) }\end{array}$ & $\begin{array}{l}\text { Acartia } \\
\text { clausi } \\
\text { (no. } \mathrm{m}^{-3} \text { ) }\end{array}$ & $\begin{array}{l}\text { Centro- } \\
\text { pages } \\
\text { typicus } \\
\left(\text { no. } \mathrm{m}^{-3}\right)\end{array}$ & $\begin{array}{l}\text { Labidocera } \\
\text { wollastoni } \\
\text { (no. } \mathrm{m}^{-3} \text { ) }\end{array}$ \\
\hline \multicolumn{10}{|c|}{ Sharks absent } \\
\hline Mean & 1.03 & 951.97 & 597.87 & 1.31 & 160.29 & 157.99 & 28.38 & 6.25 & 1.01 \\
\hline SE & 0.07 & 155.76 & 106.22 & 0.05 & 23.64 & 41.09 & 3.26 & 2.01 & 0.37 \\
\hline Median & 0.90 & 662.02 & 335.85 & 1.24 & 90.57 & 73.59 & 23.59 & 0.71 & 0 \\
\hline \multicolumn{10}{|c|}{ Sharks present } \\
\hline Mean & 1.80 & 1698.80 & 1473.74 & 1.96 & 67.31 & 121.18 & 18.91 & 14.89 & 0.50 \\
\hline $\mathrm{SE}$ & 0.19 & 329.62 & 302.12 & 0.04 & 14.35 & 19.08 & 2.44 & 6.68 & 0.21 \\
\hline Median & 1.45 & 1049.06 & 696.23 & 2.04 & 19.81 & 71.70 & 15.09 & 3.77 & 0 \\
\hline
\end{tabular}

feeding, the zooplankton density was 1.5 times greater, while the number of copepods was 1.8 times higher and the mean length of copepods was slightly increased (1.2 times). The numbers of cladocerans, chaetognaths and larvaceans were lower $(0.3$ to 0.6 times) in shark samples than in non-shark samples, although the numbers of mysid and decapod larvae and fish post-larvae, larvae and eggs were not different between areas. This preliminary study suggested copepods to be of some importance in defining basking shark feeding locations.

A more detailed analysis of a higher number of samples collected in 1996 confirmed calanoid copepods as the dominant group in all samples ( $\mathrm{n}=110$ ), with Calanus helgolandicus the predominant copepod. It was evident from the results of the qualitative analysis that distributions of ranked parameter values were different for zooplankton samples taken near sharks, compared to those taken when sharks were absent. Taking the ranks of shark and non-shark samples together, but for each parameter separately, shark samples made up $71 \%$ (zooplankton density), 58\% (numbers of copepods), $65 \%$ (number of C. helgolandicus) and $80 \%$ (C. helgolandicus mean length) of the upper half of the ranked parameter values (between ranks 1 and 55). This demonstrated an assessment that of all samples taken, with consideration of each of 4 parameters separately (zooplankton density, numbers of copepods, numbers of $C$. helgolandicus and $C$. helgolandicus mean length), samples taken near feeding sharks accounted for between 58 and $80 \%$ of the upper $50 \%$ of all values. Hence, there were positively skewed dispersions for the 4 zooplankton characteristics analysed in shark samples compared to non-shark samples

The quantitative statistical analyses showed zooplankton density was 1.8 times higher in shark samples $(n=60)$ and the median density of zooplankton was significantly greater than in non-shark samples $(n=50)$ (Table $2 ; t_{0.0511110}=1.98, Z=3.59, \mathrm{p}<0.001$ ). However, the median number of all copepods per $\mathrm{m}^{3}$ was not significantly different between shark and non-shark samples in a separate test $\left(t_{0.05(2), 110}=1.98, Z=1.52, p>\right.$ $0.10)$, even though the mean number of all zooplankton was 1.8 times greater from samples near sharks. By consideration of the species numbers of copepods present, the lack of difference between numbers of all copepods can be accounted for. Where sharks were feeding the number of Calanus helgolandicus was 2.5 times greater, the median number per $\mathrm{m}^{3}$ significantly higher $\left(t_{0.05(2), 110}=1.98, Z=2.70, p<0.01\right)$, and of a greater mean length (1.5 times) $\left(t_{0.05(2) .110}=1.98, Z=\right.$ $7.62, \mathrm{p}<0.001)$ than $C$. helgolandicus in non-shark samples (Table 2). In areas where sharks were absent there were 2.4 times more Temora longicornis, and 1.5 times as many Acartia clausi, with the median density being significantly greater for each species compared to samples taken near feeding sharks ( $T$ longicornis, $t_{0.05(2), 110}=1.98, Z=4.12, p<0.001 ;$ A. clausi, $t_{0.05(2), 110}=$ $1.98, Z=2.30, \mathrm{p}<0.01$ ). The median numbers of Pseudocalanus elongatus, Centropages typicus and Labidocera wollastoni were not different between shark and non-shark samples $(Z=0.36$ to 0.41 , all $p>$ 0.50 ) (Table 2).

To provide an indication of temporal as well as spatial differences in characteristics of zooplankton, samples taken in 1996 at the stations when sharks were absent, but before or after sharks were sighted feeding that day $(n=17$ ), were compared to samples taken at stations when sharks were absent, and when no sharks were seen that day $(\mathrm{n}=33)$ (Table 3$)$. In samples taken before or after shark presence on a particular day, the mean and median zooplankton density, number of copepods and number of Calanus helgolandicus and Pseudocalanus elongatus were higher than in samples from stations when sharks were absent on that day (Table 3). However, the mean length of $C$. helgolandicus and the number of $T$. longicornis and Acartia clausi were not dissimilar between these 2 sample sets. 
Table 3. Zooplankton density and copepod species abundances measured in 1996 when sharks were absent on a particular day $(n=33)$ and when sharks were absent when samples were taken but were seen either before or after sampling ( $\mathrm{n}=17)$

\begin{tabular}{|c|c|c|c|c|c|c|c|c|c|}
\hline & $\begin{array}{l}\text { Density } \\
\left(\mathrm{g} \mathrm{m}^{-3}\right)\end{array}$ & $\begin{array}{l}\text { Copepods } \\
\left(\text { no. } \mathrm{m}^{-3}\right)\end{array}$ & $\begin{array}{l}\text { Calanus } \\
\text { helgo- } \\
\text { landicus } \\
\left(\text { no. } \mathrm{m}^{-3}\right)\end{array}$ & $\begin{array}{c}\text { C. helgo- } \\
\text { landicus } \\
\text { mean length } \\
(\mathrm{mm})\end{array}$ & $\begin{array}{c}\text { Temora } \\
\text { longicornis } \\
\left(\text { no. } \mathrm{m}^{-3}\right)\end{array}$ & $\begin{array}{l}\text { Pseudo- } \\
\text { calanus } \\
\text { elongatus } \\
\left(\mathrm{no}^{-3} \mathrm{~m}^{-3}\right)\end{array}$ & $\begin{array}{l}\text { Acartia } \\
\text { clausi } \\
\text { (no. } \mathrm{ma}^{-3} \text { ) }\end{array}$ & $\begin{array}{l}\text { Centro- } \\
\text { pages } \\
\text { typicus } \\
\left(\text { no. } \mathrm{m}^{-3}\right)\end{array}$ & $\begin{array}{l}\text { Labidocera } \\
\text { wollastoni } \\
\text { (no. } \mathrm{m}^{-3} \text { ) }\end{array}$ \\
\hline \multicolumn{10}{|c|}{ Sharks absent } \\
\hline Mean & 0.81 & 593.27 & 329.45 & 1.31 & 154.93 & 73.00 & 30.30 & 3.90 & 1.41 \\
\hline $\mathrm{SE}$ & 0.04 & 67.37 & 38.66 & 0.07 & 28.72 & 13.54 & 4.26 & 1.99 & 0.45 \\
\hline Median & 0.77 & 641.51 & 301.89 & 1.21 & 109.43 & 60.34 & 30.19 & 0.47 & 0 \\
\hline \multicolumn{10}{|c|}{ Before/after shark presence } \\
\hline Mean & 1.44 & 1648.28 & 1118.92 & 1.31 & 170.70 & 322.97 & 24.64 & 10.82 & 1.41 \\
\hline $\mathrm{SE}$ & 0.13 & 394.35 & 265.11 & 0.06 & 43.82 & 109.29 & 5.12 & 4.42 & 0.45 \\
\hline Median & 1.29 & 783.02 & 490.57 & 1.33 & 71.70 & 120.75 & 15.09 & 1.88 & 0 \\
\hline
\end{tabular}

Discussion. It has been proposed on the basis of stomach dissections that the basking shark is an indiscriminate plankton feeder that filters the dominant constituent of the plankton at any particular time and place (Matthews \& Parker 1950). Post mortem studies on basking shark stomachs have noted that calanoid copepods were generally the predominate prey group (Matthews \& Parker 1950, Watkins 1958). Matthews \& Parker (1950) found Calanus and other copepods, in addition to fish eggs, cirripede and decapod larvae. Records of the copepods Oithona, Calanus, and Pseudocalanus have also been made from basking shark stomach contents (Sproston 1948 cited in Matthews \& Parker 1950). The zooplankton species identified from shark feeding areas in the current study were those most commonly present off Plymouth, i.e. C. helgolandicus, $P$. elongatus, Temora longicornis, Centropages typicus and Acartia clausi (Marine Biological Association 1957, Green et al. 1993). The present study was a comparison of zooplankton characteristics between areas where basking sharks were feeding and were absent. It shows that basking sharks surface feed in areas where larger ( $2 \mathrm{~mm}$ long) $C$. helgolandicus predominate $\left(\sim 1500 \mathrm{~m}^{-3}\right)$ concomitant with low numbers of smaller zooplankton species, such as $T$. longicornis, A. clausi and cladocerans (all $\sim 0.5$ to $1 \mathrm{~mm}$ in length). The combination of these zooplankton characteristics resulted in the observed increase in biomass per $\mathrm{m}^{3}$ where basking sharks were feeding compared to sea areas where absent. That basking sharks feed in areas rich in large $C$. helgolandicus is further supported by the observation of higher numbers of $C$. helgolandicus and $P$. elongatus and lower numbers of smaller species in samples taken before and after feeding sharks were seen in adjacent locales to the sample stations on the same days. However, the mean length of $C$. helgolandicus was not different, perhaps suggesting one reason why basking sharks were not feeding in these areas but elsewhere in the vicinity.
Zooplankton characteristics in sea areas supporting surface feeding basking sharks have never been described previously. Whilst the assertion that Cetorhinus maximus feed indiscriminately on plankton is accepted in the absence of information regarding filtering efficiency and more detailed stomach contents analysis, the current study suggests that basking sharks do not merely feed in all locations, but that their presence is dependent upon specific zooplankton characteristics. The right whale Eubalaena glacialis exhibits similar behaviour to basking sharks. It filterfeeds at the surface by swimming with its mouth open, trapping zooplankton on filaments attached to the inside surface of the baleen plates (Mayo \& Marx 1990). In the north Pacific and Atlantic E. glacialis feeds on calanoid copepods (Braham \& Rice 1984). In Cape Cod Bay, Massachusetts, USA, surface feeding right whales orient to zooplankton patches with a mean calanoid copepod concentration of approximately 2500 organisms per $\mathrm{m}^{3}$ (Mayo \& Marx 1990). These whales remained within patches by means of convoluted swimming paths, and it has been suggested that they are able to do this by tracking variations in patch density and modifying their movements accordingly (Mayo \& Marx 1990). Like the right whale, basking sharks may also orient to waters rich in large calanoid copepods, perhaps by using a similar behavioural strategy of area-restricted searching. Therefore, on the basis of our findings we suggest that basking sharks actively forage to locate zooplankton patches of specific characteristics, namely, high abundance of large copepod species (i.e. Calanus helgolandicus) and lower relative abundance of smaller zooplankton species.

Filter-feeders such as basking sharks must obtain enough energy from planktonic food to meet the cost of collecting it, before energy can be partitioned into somatic and gonadal growth. To avoid feeding at a loss (or sustained intake at only a maintenance level), high 
concentrations of plankton must be located by basking sharks during the summer feeding season. In light of the present investigation, basking sharks could use foraging behaviours that facilitate orientation to productive plankton patches so as to maximise energy intake. Although this study is suggestive of basking sharks selecting feeding locations on the basis of specific zooplankton characteristics, the bases of orientation decisions necessary to achieve this assumed goal need to be investigated directly

Acknowledgements. The authors thank Mr R. S. Kings for kindly providing sea-time in 1995 and without whose support this research would not have begun. The 1996 study was supported by the Nature Conservancy Council for England (English Nature). Dr Q. Bone, FRS, Dr P. J. Reay, and 2 anonymous reviewers are thanked for their valuable comments on earlier versions of this manuscript.

\section{LITERATURE CITED}

Berrow SD, Heardman C (1994) The basking shark Cetorhinus maximus (Gunnerus) in Irish waters - patterns of distribution and abundance. Proc R Irish Acad 94B:101-107

Braham HW, Rice DW (1984) The right whale, Balaena glacialis. Mar Fish Rev 46:38-44

Compagno LJV (1984) FAO species catalogue, Vol 4, Sharks of the world, Part 1, Hexanchiformes to Lamniformes. FAO Fisheries Synopsis

Editorial responsibility: Otto Kinne (Editor),

Oldendorf/Luhe, Germany
Diamond JM (1985) Filter-feeding on a grand scale, Nature 316:679-680

Green EP, Harris RP, Duncan, A (1993) The seasonal abundance of the copepodite stages of Calanus helgolandicus and Pseudocalanus elongatus off Plymouth. J Mar Biol Assoc UK 73:109-122

Hallacher LE (1977) On the feeding behaviour of the basking shark, Cetorhinus maximus. Environ Biol Fish 2 297-298

Kenney RD, Owen RE, Winn HE (1985) Shark distributions off the northeast United States from marine mammal surveys. Copeia 1985:220-223

Marine Biological Association (1957) Plymouth marine fauna. Marine Biological Association, Plymouth

Matthews LH, Parker HW (1950) Notes on the anatomy and biology of the basking shark (Cetorhinus maximus (Gunner)\}. Proc Zool Soc Lond 120:535-576

Mayo CA, Marx MK (1990) Surface foraging behaviour of the north Atlantic right whale, Eubalaena glacialis, and associated zooplankton characteristics. Can J Zool 68 $2214-2220$

Parker HW, Boeseman M (1954) The basking shark (Cetorhinus maximus) in winter. Proc Zool Soc Lond 124 $185-194$

Tait RV (1980) Elements of marine ecology. Butterworths, London

Todd CD, Laverack MS, Boxshall GA (1996) Coastal marine zooplankton. Cambridge University Press, Cambridge

Watkins A (1958) The sea my hunting ground. William Heinemann, London

Zar JH (1984) Biostatistical analysis. Prentice-Hall, Englewood Cliffs, NJ

Submitted: February 19, 1997; Accepted: September 22, 1997 Proofs received from author(s): October 23, 1997 